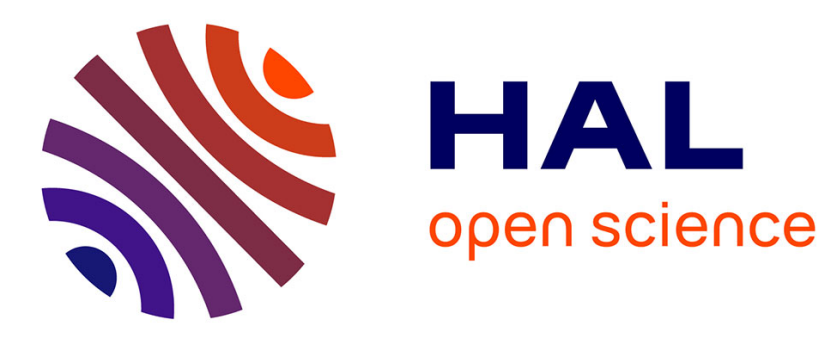

\title{
Shunsuke Managi, Koichi Kuriyama, 2017, Environmental Economics, New York, USA, Routledge Textbooks In Environmental and Agricultural Economics, $232 \mathrm{p}$
}

François Salanié

\section{To cite this version:}

François Salanié. Shunsuke Managi, Koichi Kuriyama, 2017, Environmental Economics, New York, USA, Routledge Textbooks In Environmental and Agricultural Economics, 232 p. Review of Agricultural, Food and Environmental Studies, 2017, 98 (4), pp.321-322. 10.1007/s41130-018-0065-x . hal-03114847

\section{HAL Id: hal-03114847 \\ https://hal.science/hal-03114847}

Submitted on 19 Jan 2021

HAL is a multi-disciplinary open access archive for the deposit and dissemination of scientific research documents, whether they are published or not. The documents may come from teaching and research institutions in France or abroad, or from public or private research centers.
L'archive ouverte pluridisciplinaire $\mathbf{H A L}$, est destinée au dépôt et à la diffusion de documents scientifiques de niveau recherche, publiés ou non, émanant des établissements d'enseignement et de recherche français ou étrangers, des laboratoires publics ou privés. 


\title{
Shunsuke Managi, Koichi Kuriyama, 2017, Environmental Economics, New York, USA, Routledge Textbooks In Environmental and Agricultural Economics, 232 p
}

\author{
François Salanié ${ }^{1}$
}

Published online: 9 March 2018

C) INRA and Springer-Verlag France SAS, part of Springer Nature 2018

This book is not an additional textbook on environmental economics. It is an attempt at conveying the main tools and findings of this field of study to an audience without any "formal knowledge in economics": government advisors, business people, or policymakers. Such an objective makes the book original in many respects, as we shall see.

The authors are university professors with a dedication to empirical and applied works, and a strong involvement in the management of environmental problems, especially in the domain of urban economics. One may hypothesize that the idea of the book emerged during one more frustrating meeting with policymakers who unfortunately were not able to apply the standard economic approach to address a practical issue. Since policymakers are busy people with no inclination for academic works, one therefore had to first describe realworld problems before gradually introducing economic concepts and results. This is the approach followed in this book, in strong contrast with more academic textbooks. In that respect, the title of the book could have included a qualifier ("env. eco. for practitioners") in order to make its ambitions more manifest.

While the motivation for the book is laudable, one should not hide the difficulties of the task. For example, the first chapter rapidly documents a few important questions about the link between growth and the environment, but in fact mainly focuses on two case studies: waste disposal in Japan and climate change. This last topic is covered in seven pages, with the following roadmap: first, facts about global warming and energy consumption; then the basics of demand and supply, and the result that surplus is maximized when supply equals demand; and finally the observation that the market for energy does not "properly account for climate change and its effects". It is indeed a tour-de-force to introduce so many concepts in a few pages.

François Salanié

francois.salanie@inra.fr

1 Toulouse School of Economics, INRA, Université de Toulouse Capitole, Toulouse, France 
Such a tour-de-force raises two questions. The first one is whether one can really transmit the fundamental content of the economic approach in such a short book. I could not find any allusion to General Equilibrium Theory or to Public Economics in the chapters devoted to theory (chapters 2 and 3). And as illustrated above by the example of surplus maximization, there are deep results in economics, and understanding them usually requires more space.

The second question is whether one can transmit the structure of the economic approach by relying on case studies. For example, the result that taxes dominate subsidies because the latter lead to over-optimal entry can be deduced from general equilibrium theory. Instead the book proceeds to a comparison of simple pros and cons of these instruments in a discussion that lacks structure (end of chapter 3). The reader may also wonder why an abstract discussion of Weitzman's paper about prices vs. quantities takes place in a chapter 4 devoted to applications. Here also, there are issues of structure and priorities: what is important or general could be highlighted more clearly.

On the other hand, the book manages to introduce the reader to a number of important facts and debates. A policymaker without prior knowledge would indeed end up being quite well-informed about waste disposal, climate change, fisheries, and even biodiversity. He would also learn a lot about corporate social responsibility, revealed and stated preferences, cost-benefit analysis, or the value of a statistical life. All these topics are dealt with in chapter 4 to 6 , where each topic is used as an opportunity to present techniques and open questions. The material is clearly organized, and the authors rightfully prefer concision over verbosity. I was less convinced by chapter 7 about global environmental problems, such as trade or green technology. The discussions therein relate more to existing trends at the time the book was written, and less to analysis and structural arguments. And here also, why a paragraph on the Kuznets curve takes place there and not in another chapter is also unclear.

Overall, it is important to recognize the originality of the project. Writing a book that has value to readers without any former knowledge of economics is a very useful task, and the authors often strike the right balance between facts and theory. Managing to integrate all this information in such a short book is also a performance. The book will be useful, less to students than to policymakers or advisors that look for synthetic introductions to existing environmental problems. 